\title{
RENAL REPLACEMENT THERAPY IN PATIENTS WITH HEART AND KIDNEY FAILURE
}

\author{
Dimitrios S Goumenos, Evangelos Papachristou, Marios Papasotiriou \\ Department of Nephrology and Renal Transplantation, University Hospital of Patras, Greece \\ Corresponding Author: Prof. Dimitrios S. Goumenos, Department of Nephrology and Renal Transplantation, \\ University Hospital of Patras, 26500 Patras, Greece; tel.: 0030 2613603361, fax: 003026109944424; \\ e-mail:dgoumenos@upatras.gr
}

\begin{abstract}
The incidence of chronic kidney disease (CKD) in patients with chronic heart failure (CHF) is high as CKD and CHF share underlying risk factors such as arterial hypertension, diabetes mellitus and atherosclerosis. Cardiac failure leads to renal hypoperfusion and dysfunction and then fluid overload and need for aggressive diuretic therapy. However, development of diuretic resistance represents a significant problem in the management of these patients.

The role of Renal Replacement Therapy (RRT) is important for patients who do not response to conservative management of fluid overload facilitating the failing heart to restore function. According to the guidelines, venovenous isolated Ultrafiltration (UF) is indicated for patients with refractory congestion not responding to medical therapy with loop diuretics and infusion of dopamine. A systematic review of randomized controlled trials on the effect of UF vs. IV furosemide for decompensated heart failure showed a benefit of UF on total body weight loss and on readmissions due to heart failure in patients with decompensated heart failure and CKD. Peritoneal dialysis (PD) can provide efficient ultrafiltration and sodium extraction in volume overloaded patients followed by decline of hospitalization days, decrease of body weight and improvement of LVEF in patients with refractory heart failure. The continuous draw of ultrafiltrate is followed by a lesser risk of abrupt hypotension and better preservation of the residual kidney function. This represents a significant advantage of PD over intermittent UF by dialysis.

In conclusion, application of UF by dialysis and PD is followed by significant total body weight loss, reduced need for hospital readmissions and better quality of life. PD has a higher probability of preservation of residual kidney function and can be used by patients at home.
\end{abstract}

Key words: heart failure, chronic kidney disease, ultrafiltration, peritoneal dialysis

\section{Epidemiology, pathophysiology}

The incidence of chronic kidney disease (CKD) in patients with chronic heart failure (CHF) is high as both share underlying risk factors such as arterial hypertension, diabetes mellitus and atherosclerosis. There is abidirectional interplay as cardiac failure leads to renal hypoperfusion and dysfunction that is followed by fluid overload and need for aggressive diuretic therapy. However, the effectiveness of diuretics might be hampered by development of diuretic resistance and the use of renal replace- ment therapy becomes necessary. The decompensated heart failure in patients with CKD leads to prolonged hospitalizations, significant morbidity and increased mortality [1, 2].

Loop diuretics should be used as firstline agents if GFR is below $30 \mathrm{ml} / \mathrm{min}$. Thiazide diuretics are not effective if used alone in patients with GFR $<30 \mathrm{ml} / \mathrm{min}$. Strategies improving loop diuretic responsiveness in CKD patients with heart failure include reduced salt intake (up to $2 \mathrm{~g}$ /day but not less), intravenous bolus furosemide (up to $2 \mathrm{~g}$ /day) instead of oral 
administration of equivalent dose especially in cases with fluid overload (edema exists also in the gut) and co-administration of hydrochlorothiazide or metolazone in cases with resistance to loop diuretics. Such patients need close monitoring in order to prevent adverse effects such as decrease in renal perfusion, hypovolemia, hypokalemia, hyponatremia and hypomagnesemia $[2,3]$. Severe volume overload with very low cardiac output leads to significant impairment of renal perfusion, decrease of GFR and failure to deliver diuretics to their site of action. This is followed by release of norepinephrine, angiotensin II, aldosterone and vasopressin leading to systemic and renal vasoconstriction, renal salt and water retention with further deterioration of fluid overload and decrease of cardiac output [3, 4].

\section{Role of renal replacement therapy (RRT)}

The role of Renal Replacement Therapy (RRT) is important for patients with no response to conservative management (administration of diuretics) who have fluid overload, pulmonary edema, hyperkalemia, decreased urine output, severe hyponatremia and metabolic acidosis. Fluid removal by extracorporeal therapy has clear-cut benefits in patients with volume overload and pulmonary edema supporting the failing heart to restore function.

Intermittent isolated ultrafiltration (IUF) is a process resembling to conventional hemodialysis. It is performed via a dual lumen catheter inserted in a large central vein in intermittent sessions of 1-4 hours where a goal volume removal is set. Fluid removal is based on a pressure gradient established between blood and UF compartment and in contrast to hemodialysis no dialysate is used $[1,4]$.

According to the guidelines of the American Heart Association and European Society of Cardiology on the use of ultrafiltration (UF) in heart failure, venovenous isolated UF is indicated for patients with refractory congestion not responding to medical therapy and in particularly if doubling of the dose of loop diuretics and infusion of dopamine do not result in an adequate diuresis and the patient remains in pulmonary edema.

In the RAPID-CHF Trial 40 pts admitted for CHF with evidence of volume overload were randomized to a single, 8 hours UF session in addition to usual care or usual care alone. After 24 hours there was a significant difference in the fluid removal between two groups $(4.6 \mathrm{~L}$ in the UF vs. $2.8 \mathrm{~L}$ in the usual care groups, $p=0.001$ ) but no significant difference in weight loss. This early application of UF for patients with CHF was well-tolerated [5]. In the UNLOAD trial 200 pts hospitalized for HF with more than 2 signs of hypervolemia were randomized to UF or IV diuretics. After 48 hours, weight loss and net fluid loss were greater in the UF group $(5.0 \mathrm{~kg}$ vs. $3.1 \mathrm{~kg}, \mathrm{p}=$ 0.001 and $4.6 \mathrm{l}$ vs. 3.3l, $\mathrm{p}=0.001$, respectively). At 90 days the UF group had fewer patients rehospitalized for HF (18\% vs. 32\%, $\mathrm{p}=0.037$ ) and fewer rehospitalization days (1.4 vs. 3.8, p $=0.022$ ) per patient. However, no differences were observed in the mortality rate and serum creatinine between the two groups [6]. In the CUORE trial 56 pts with CHF were randomized to standard medical therapy or UF [7]. The primary endpoint was rehospitalizations for CHF during a 1-year follow-up. Despite similar body weight reduction at hospital discharge in the 2 groups, a lower incidence of rehospitalizations for HF was observed in the UF-treated patients. UF induced benefit was associated with a more stable renal function, unchanged furosemide dose, and lower B-type natriuretic peptide levels. According to this study the use of UF as first-line treatment in patients with HF and severe fluid overload is associated with prolonged clinical stabilization and less need for rehospitalization for congestive HF (7). A systematic review with meta-analysis of randomized controlled trials on the effect of UF vs. IV furosemide for decompensated heart failure in cardiorenal syndrome showed a benefit of UF on total body weight loss in patients with decompensated heart failure and CKD and also on readmissions due to heart failure in patients with decompensated heart failure and chronic kidney disease [8].

The advantages of UF are symptomatic relief due to fluid removal with better gas exchange and decrease work of breathing, improved cardiac function and breaking of the vicious cycle that makes such patients diureticrefractory, increase of blood pressure, reduction in renal venous congestion and improvement in renal hemodynamics and urine output, higher mass clearance of sodium, decreased 
risk of electrolyte abnormalities (e.g., hypokalemia), lack of neurohormonal activation (SNS, RAAS, and AVP), decreased rate of heart failure-related rehospitalizations and decreased hospital length of stay [4, 9].

The disadvantages of UF are hemodynamic stress and instability because of large volume removal in short period of time, lack of protective effect on renal function, lack of effect on markers of mortality (i.e. serum $\mathrm{Na}$ and BUN), need for placement of midline or central venous catheter and additional training for staff and physicians, need for anticoagulation, complications related to extracorporeal circuit (e.g., allergic reaction, air embolism, hemolysis, infection, and bio-incompatibility), lack of widely accepted guidelines for its use (e.g., patient population, indications, timing of initiation and termination, and UF rate/volume), lack of knowledge on the long-term outcomes and high cost (device and disposables) [4, 9].

\section{Peritoneal Dialysis (PD) in patients with heart failure}

Peritoneal dialysis (PD) can provide efficient ultrafiltration and sodium extraction in volume overloaded patients (especially through the use of icodextrin solution) with simultaneous correction of the metabolic consequences of reduced renal function. The limited experience from trials on PD in patients with heart and kidney failure has shown the safety and efficacy of this therapeutic modality suggesting that it could represent a relevant option for such patients. Several uncontrolled PD studies have favourable results despite the fact that PD was restricted to very ill patients, refractory to alternative options who were not candidates for heart transplant [10].

In a multicenter retrospective study 48 patients with severe HF refractory to maximized drug treatment were treated by PD ultrafiltration (PUF). The patients were proposed for PUF because they had experienced at least 3 hospital admissions in the preceding year for acutely decompensated HF requiring extractorporeal UF. Out of 48 patients, 30 received 1 nocturnal icodextrin exchange, 5 required 2 daily exchanges, and 13 received 2-4 sessions per week of PD. During the first year, renal function remained stable (20.8 vs. $22.0 \mathrm{~mL} / \mathrm{min} / 1.73 \mathrm{~m}^{2}$ ), pulmonary artery systolic pressure declined (p
$=0.03$ ) and there was a significant improvement in New York Heart Association functionnal status. Hospitalizations decreased from 43days/patient-year before the start of PUF to 11days/patient-year $(\mathrm{p}<0.001)$ whereas patient survival was $85 \%$ at 1 year and $56 \%$ at 2 years [11]. In another retrospective analysis, 127 patients were treated with PD for management of chronic refractory HF (mean e-GFR: $33.5 \pm 15$ $\mathrm{mL} / \mathrm{min} / 1.73 \mathrm{~m}^{2}$ ). Patients with low left ventricular ejection fraction (LEVF) experienced significant improvement after PD. Furthermore PD was associated with a dramatic reduction in the number of days of HF-related hospitalization. During the year before PD initiation, each patient stayed at hospital for an average of 3.3 \pm 2.6 days/month whereas after PD the number of hospitalization days declined to $0.3 \pm 0.5$ days/month ( $\mathrm{p}<0.0001)$, corresponding to a $91 \%$ reduction in hospital stay [12]. Thus, PD therapy could be effective for patients with chronic heart failure in whom conventional therapies have not been associated with significant therapeutic response. These results were confirmed in a recent analysis of 21 published studies on PD for patients with refractory heart failure. After PD, hospitalization days declined, body weight decreased and LVEF improved significantly. This analysis also demonstrated that the yearly average peritonitis rate was $14.5 \%$, and the average yearly mortality was $20.3 \%$ [13].

PD continuously draws ultrafiltrate by the osmotic power of the PD solution and therefore has a lesser risk of abrupt hypotension that would exaggerate organ hypoxia and kidney damage. Furthermore better preservation of the residual kidney function by PD represents an advantage of PD over intermittent UF. It should be noted that $\mathrm{Na}$ removal is higher than that in urine produced by furosemide since ultrafiltrate $\mathrm{Na}$ level is about $100 \mathrm{mmol} / \mathrm{L} \mathrm{[14]}$. Use of PD at home for patients with heart failure could potentially lead to significant savings in healthcare expenditure while providing a better quality of life for patients. In patients with significant residual renal function who do not require dialytic support, nocturnal automated PD or a single night time exchange with icodextrin solution could be sufficient to maintain euvolemia. This means that depending on the severity of HF, PD therapy can be used only a few nights a week. The risk of peri- 
tonitis that might be a drawback for the use of PD is low nowadays [14, 15]. However, it seems that despite the beneficial effect of PD in patients with HF, it does not alter the natural history of the disease and probably does not influence the survival of these patients. Furthermore the experience on the use of PD in such patients is very limited and this is probably the reason why PD is not yet considered by the cardiology societies as a therapeutic option for HF. Future prospective randomized trials with longer follow-up periods comparing PD with UF by dialysis could address this issue and establish PD as a proper treatment modality for patients with HF [15].

\section{Conclusions}

The management of patients with decompensated heart failure and CKD is usually difficult because of the development of diuretic resistance. The application of UF by dialysis and PD is followed by significant total body weight loss, reduced need for readmissions to the hospital and better quality of life. PD has a lesser risk of abrupt hypotension, a higher probability of preservation of residual kidney function and it can be used by the patients at home. Further research with randomized controlled trials is necessary in order to establish $\mathrm{PD}$ in the management of patients with HF.

\section{REFERENCES}

1. Udani SM and Murray PT. The use of renal replacement therapy in acute decompensated heart failure. Semin Dial. 2009; 22: 173-179.

2. Verbrugge FH, Grieten L, Mullens W. Management of the cardiorenal syndrome in decompensated heart failure. Cardiorenal Med. 2014; 4: 176-188.

3. Forman DE, $\mid$ Butler J, Whang Y, Abraham WT et al. Incidence, predictors at admission, and impact of worsening renal function among patients hospitalized with heart failure. J Am Coll Cardiol. 2004; 43: 61-67.

4. Kazory A. Cardiorenal syndrome: ultrafiltration therapy for heart failure-trials and tribulations. Clin J Am Soc Nephrol. 2013; 8: 1816-1828.

5. Bart BA, Boyle A, Bank AJ, Anand I, et al. Ultrafiltration versus usual care for hospitalized patients with heart failure: the Relief for Acutely FluidOverloaded Patients With Decompensated Congestive Heart Failure (RAPID-CHF) trial. J Am Coll Cardiol. 2005; 46: 2043-2046.
6. Costanzo MR, Guglin ME, Saltzberg MT, Jessup ML, et al. UNLOAD Trial Investigators. Ultrafiltration versus intravenous diuretics for patients hospitalized for acute decompensated heart failure. J Am Coll Cardiol. 2007; 49: 675-683.

7. Marenzi G, Muratori M, Cosentino ER, Rinaldi ER, et al. Continuous ultrafiltration for congestive heart failure: the CUORE trial. J Card Fail. 2014; 20: 9-17.

8. Chen HY, Chou KJ, Fang HC, Chen CL, et al. Effect of ultrafiltration versus intravenous furosemide for decompensated heart failure in cardiorenal syndrome: a systematic review with meta-analysis of randomized controlled trials. Nephron. 2015; 129(3): 189-96.

9. Krishnamoorthy A and Felker GM. Fluid removal in acute heart failure: diuretics versus devices. Curr Op Crit Care. 2014; 20: 478-483.

10. Nakayama M. Nonuremic indication for peritoneal dialysis for refractory heart failure in cardiorenal syndrome type II: review and perspective. Perit Dial Int. 2013; 33: 8-14.

11 Bertoli SV, Musetti C, Ciurlino D, Basile C, et al. Peritoneal ultrafiltration in refractory heart failure: a cohort study. Perit Dial Int. 2014; 34: 64-70.

12 Courivaud C, Kazory A, Crépin T, Azar R, et al. Peritoneal dialysis reduces the number of hospitalizetion days in heart failure patients refractory to diuretics. Perit Dial Int 2014; 34: 100-108.

13 Lu R, Muciño-Bermejo MJ, Ribeiro LC, Tonini E, et al. Peritoneal dialysis in patients with refractory congestive heart failure: a systematic review. Cardiorenal Med. 2015; 5: 145-156.

14 Puttagunta $\mathrm{H}$ and Holt SG. Peritoneal Dialysis for Heart Failure. Perit Dial Int. 2015; 35: 645-649.

15. Kazory A. Peritoneal dialysis for chronic cardiorenal syndrome: Lessons learned from ultrafiltration trials. World J Cardiol. 2015; 26: 392-396.

Резиме

\section{ЗАМЕНСКА БУБРЕЖНА ТЕРАПИЈА КАЈ ПАЦИЕНТИ СО СРЦЕВА И БУБРЕЖНА СЛАБОСТ}

\section{Димитриос С. Гуменос, Евангелос Папахристу, Мариос Папасотириу}

Клиника за нефрологија и трансплантација на бубрези, Универзитетска болница во Патра, Грција

Инциденцата на хроничната бубрежна болест (ХББ) кај пациенти со хронична срцева слабост (ХБС) е на високо ниво, бидејќи ХББ и ХБС ги споделуваат основните фактори на ризик, како што се артериска хипертензија, дијабетес мелитус и атеросклероза. Срцевата слабост води 
кон бубрежна хипоперфузија и дисфункција, а потоа и преоптоварување со течност и потреба од агресивна терапија со диуретици. Сепак, развојот на отпор кон диуретик претставува значаен проблем во лечењето на овие пациенти.

Улогата на заменска бубрежна терапија (ЗБТ) е значајна за пациентите кои не реагираат на конзервативното лечење и за олеснување од преоптоварувањето на срцето со течности, за да ce врати на функција. Во согласност со насоките, венски изолираната ултрафилтрација (УФ) е индицирана кај пациенти со рефракторна конгестија што не реагираат на медицинската терапија со диуретици и инфузија на допамин и пациентот останува во белодробен едем. Систематскиот преглед на рандомизирани контролирани испитувања на ефектот на УФ наспроти интравенозен фуросемид за декомпензирана срцева слабост покажа корист од УФ на вкупната загуба на телесната тежина и на повторен прием во болница поради срцева слабост кај пациенти со декомпензирана срцева слабост и ХББ. Пери- тонеалната дијализа (ПД) може да обезбеди ефикасна ултрафилтрација и вадење на натриумот кај пациенти преоптоварени со волумен, проследено со намалување на деновите на хоспитализација, намалување на телесната тежина и подобрување на LVEF кај пациентите со рефракторна срцева слабост. Постојаното повлекување на ултрафилтратот е проследено со помал ризик од нагла хипотензија и подобра заштита на резидуалната бубрежна функција. Ова претставува значајна предност на ПД во однос на повремената УФ со дијализа.

Како заклучок, примената на УФ со дијализа и ПД е проследено со значителна вкупна загуба на телесна тежина, намалена потреба од повторен прием во болница и подобар квалитет на животот. ПД има поголема веројатност за зачувување на резидуалната бубрежна функција и може да ја користат пациентите дома.

Клучни зборови: срцева слабост, хронична бубрежна болест, ултрафилтрација, перитонеална дијализа 